\title{
Non-Formal Religious Education in Malay Muslim Community in Terengganu, Malaysia
}

\author{
Asyraf Hj Ab Rahman, PhD \\ Centre for Fundamental and Liberal Education, Universiti Malaysia Terengganu \\ asyraf@umt.edu.my \\ Wan Ibrahim Wan Ahmad, PhD \\ School of Social Development, Universiti Utara Malaysia \\ wiwa@uum.edu.my \\ Hammadah Hj Ab Rahman \\ Institut Perguruan Dato Razali Ismail, Kuala Terengganu \\ hammadah_1975@yahoo.com.my
}

\section{Doi:10.5901/mjss.2015.v6n3s2p189}

\begin{abstract}
Terengganu is known as one of the center of religious traditional educations since many decades. The emergence of several traditional religious schools known as pondok has had a great impact on Muslim community in the area. The school used traditional mode of teaching methods and commonly handled in a study circle or halaqah guided by kitab kuning or old book as text books. Up to the present day, though some pondok schools are gradually replaced by modern schools receiving financial supports from the government, the traditional mode of teaching in the pondok are still popular including in some mosques of the state. This paper discusses the forms of teaching methods of religious education in the mosques and the pondok, besides looking at some roles of religious education to the Malay community. Data for the study were collected through unstructured interviews with key informants, coupled with participant observations conducted in selected mosques and pondok, besides published materials from secondary sources. All the data were analyzed using thematic approach. The study shows that there are various forms of classes and teaching methods conducted in the mosques and pondok schools whilst students attending the religious classes divided into two categories, the young and the older person. With the continuing efforts by the government particularly in providing the infrastructures and financial supports, it is hoped that religious education may again showing its attraction to the surrounding Malay community.
\end{abstract}

Keywords: Islam, Religious Schools; Mosques; Pondok

\section{Introduction}

This paper presents the result of a cross-sectional study using a descriptive research design on non-formal religious education program in Malay Muslim community in Terengganu, Malaysia. Non-formal religious education, a type of nonformal education in general, refers to the education program outside the formal class room setting. Ololube and Egbezor (2012) define non-formal education as a structured education that takes place outside of an organized school setting. It can also mean any organized and sustained educational activity that does not correspond to the definition of formal education (Ololube and Egbezor, 2012). The activity within this type of education is very broad, and it can be conducted in many settings. Non-formal religious education program in this paper refers to the religious classes conducted in the selected mosques in Besut District, and two pondok schools in the district of Kuala Terengganu, Terengganu. Non-formal religious education in Malaysia is important to be analyzed as Muslim populations are the majority in Malaysia and constitute more than $60 \%$ of the whole population. This is in line with the Federal Constitution which states that Islam is the official religion of this country. Article 153 (1) of the 1957 Constitution also states that Bahasa Melayu become 'the national language' and Islam the official religion \{Article 3 (1)\}. (Abdul Rahman, 2011).

Considering the existing historical evidences and facts, Islam has long been a significant component of Malay socio-political life and culture. Among the Arab merchants and Sufis who contribute a lot to the Islamization of the Malay Peninsular are Syed Abdul Aziz, Sheikh Abdul Qadir and Syarif Karim al-Makhdum. They came from Jeddah, Saudi Arabia in the early $15^{\text {th }}$ century and were responsible towards Islamization of Malay local people including the ruler of Malacca (Chelliah,M: 1947). According to some other sources, Islam came into this Peninsular with the commitment and 
hard work of Persian Muslim merchants who had business dealings with the local Malays. Most of them came from the families of the religious elite such as the family of Asyraf Ibn Dhiauddin, the family of Jawani al-Kurdi and the family of Sabankarah (Wan Husein Azmi, 1980).

Up to the present days, Malaysian government's Islamization policies have put the role of Islam in the proper place as guaranteed by the constitution. Various religious programs and activities were carried out by the government to meet the spiritual needs of the Muslims, and at the same time would not prevent the followers of other religions to practice and perform their religious activities freely. Those programs include the establishment of new Islamic religious schools in urban and rural areas, and building new mosques as a response to the increasing numbers of Muslim population. Most of the religious programs were provided by the Malaysian government through Directorate of Islamic progress in Malaysia (JAKIM) and State Islamic Religious Departments with a strong supports from the Ministry of Education. Since 1986 for instance, the government has located a total of RM32.6 million for religious education including classes conducted in mosques and selected schools and so far, a total of 3692 religious instructors available throughout the country (Abdullah Mohamad, 2011).

After 25 years of the class operations, the program turned out great benefit and has a positive impact on Muslims in terms of financial allocations spent and students attending the classes. In additions, the continuous effort by JAKIM in directing the mosques management committees to consistently improve the role of mosques by organizing activities and services has further enhanced perception of surrounding community towards the mosques. Thus, a question that comes into the mind, how was the teaching method employed during the class session which successfully gave an impact for students? What type of books used for the class session which at the end capable of developing a good Muslim who has a solidly grounded faith, which gives him and the people around him inner and outer strength?

\section{Objective of the Study}

Considering these questions, the paper therefore tends to discuss religious education carried out in the selected mosques and pondok schools, besides analyzing its contents and methods in producing students having ability in terms of religious knowledge and skills. In particular, the present paper is aimed to discuss:

(1) The development of religious education in Terengganu,

(2) Religious classes in mosques,

(3) Religious classes in pondok school, and

(4) Role of religious education to the Malay community

\section{Literature Review}

Ahmad Shalabi in his Tarikh al-Tarbiyyah al-Islamiyyah (History of Muslim Education) devotes a section to 'Travel for Study'. He quotes the Prophet's Traditions: 'Obtaining knowledge will not be possible with bodily ease' and 'whoever sets out seeking knowledge will be walking in the path of Allah till he returns and whoever dies while travelling for learning will be regarded as a martyr (Ahmad Shalabi, 1973). Describing religious education among the Malay Muslim community in the $14^{\text {th }}$ century, Abdullah Munsyi notes that there are three important elements emphasized that always linked with Islam and centered around the Quran, Hadith (tradition) and religious law. These elements could be described as follows: 1) Studying the classical books emphasized the Oneness of Allah (tauhid), His actions (af'al) and His attributes (sifat). 2) Studying the books of figh (Islamic jurisprudence) that stress on Muslim relations (mu'amalat) and their obligations such as prayer, fasting, zakat and pilgrimage and 3) Studying various disciplines and branches of knowledge that would benefit them in their daily life such as the biography of the Prophet and the classical Islamic tales (Haron Din and Sobri Salamun, 1980).

These subjects were taught in mosques and pondok while an instructor called Tok Guru sat at the front reading a classical text and explaining its lessons words by words. There are many literatures on Pondok (among others by Ismail Ishak, 1990, Azmi Omar, 1993, and Hasan Md Man, 1990), which focused on building structure of the schools and syllabus that are taught. Albeit none of the available literatures discuss the survival of the pondok in the contexts of the modern day demands. In the $14^{\text {th }}$ to early $20^{\text {th }}$ century, mosques and pondok worked together in providing traditional Islamic education as preparatory life for students before getting into the real life in society. Mosques for instance, during the early Islam, has become not only as a place of worship, but also as social gathering and education centre for Muslims. Many studies conducted to describe the role and function of mosque from the Prophet's era up to this day. According to Muhammad Uthman (2006), the success of mosque functions becomes the responsibility of the ruling government to build, develop, manage and promote religious activities for Muslims. A study by Muhammad Abu Bakar 
(1987) on the other hand, stresses historical aspect of the mosque and its role in regards to Muslim affairs when parents sending their children to study basic Islamic knowledge and the Quranic recitation and memorization hoping their children one day become imams for prayers or Islamic scholars as once exemplified by companions of the Prophet pbuh (al-Bütiy 1999). According to Winstedt (1961), religious studies, which became their main focus in mosques during the early days were ilm al Hadith, ilm al-Kalam, Tasawwuf and Sharica, and titles such as Ihya' Ulum al-Din by Imam al Ghazali, Kitab al tawhid by Abu Shukur, Talkhis al-Minhaj by Imam al Nawawi are said to have become their text books.

\section{Materials and Methods}

This study was conducted in selected mosques in Besut district, and two pondok schools in the district of Kuala Terengganu, Terengganu. Both two districts are important for this study because, both exhibits and represents characteristics of traditional Malay Muslim life where Islamic rituals are practiced as part of the Malay culture. The study is designed with the aim to have a better understanding on how non-formal religious education conducted in these two setting in Terengganu. This paper is basically employed a descriptive research design. Descriptive research design is used when a researcher seeks a better understanding and measure how variables are naturally distributed (Yegidis and Weinbach, 2002). We applied this design as to see how the emergence of traditional religious schools known as pondok has had a great impact on Muslim community in the area, and we aim to describe it accurately. The design suitable to meet this aim is descriptive design (Newman, 2006). Data for the study were collected through unstructured interviews with key informants, coupled with participant observations conducted in selected mosques and pondok schools. These approaches are important as to look in depth how the religious teachings are conducted, type of books selected and teaching methodology employed. Published materials from secondary sources related to the subject are also reviewed. All the data were analyzed using thematic approach.

\section{Results and Discussion}

\subsection{The Development of Religious Education in Terengganu}

The development of Islamic education in Malaysia began since the coming of Islam into this country in the $13^{\text {th }}$ century. This could be traced back through various sources among which was archaeological evidence; the discovery of Batu Bersurat (stone) Terengganu, known as Prasasti of Terengganu at Tersat River, Kuala Berang in 1902/1320H. The writings on the stone indicated the existence of an Islamic government which implemented Islamic laws in this area (alAttas, 1970). Besides, there was other evidence including the conversion of Malacca Ruler into Islam. Since then, Muslim rulers have had great influence on the rapid spread of Islamic teachings in the country. The conversion of the past rulers to Islam successfully prompted their subjects to embrace the same religion. Various Islamic traditional educations emerged and were conducted in mosques and pondok schools to fill the spiritual needs of the local community. Since then, Terengganu considered as one of the earliest state in Malaysia to receive Islam. At the earlier stage, learning activities were centered at teachers or ulama houses and mosques. Such learning system was known as 'halaqah'. From time to time, religious education run in the house and mosques reached a climax in terms of an increase in number of students and the problems of study space.

Accommodation became another crucial problem for students coming from very distant areas. Then, small huts were built near the mosque and house of ulama for temporary living space known as pondok, from which the name of the type of school is later derived. The same ulama known as Tok Guru were responsible to teach students in both mosques and pondok. Student who missed the class at the mosques may again repeat his lesson at the pondok with the same instructor. This practice is continued until the present days. Pondok's students sometimes reached up to 1000 students and education at the mosque also receives great support from the Muslim community. The involvement of well-known religious figures as instructors also contributed to the increase number of students. Names like Sheikh Abdul Malik and Tokku Paloh were well known for their commitment and contribution to the development of the Islamic education in Terengganu (Shafie Abu Bakar, 1977).

Today, government's supports for religious education in mosques and pondok are immense. Through Directorate of Islamic progress in Malaysia (JAKIM), State Islamic Religious Departments, and Counsel for Islamic and Malay Cultural Affairs (Maidam), various educational programs under the names of Takmir, KAFA, Muallaim and Da'i were introduced. Most of the financial supports came from the zakat collections of individual Muslims and Islamic organizations. In Terengganu, Counsel for Islamic and Malay Cultural Affairs (MAIDAM) is responsible for collecting zakat from those Muslims eligible for its payments and later distributed the money to the religious activities mentioned above. 
Almost RM100, 000 were allocated for registered pondok institutions. There are more than 30 pondok schools in Terengganu eligible for the financial supports. For Kafa program, the financial supports were allocated through Islamic Foundation of Terengganu to be distributed to religious education at primary schools in Terengganu. Most of the money was for salary payment to Kafa teachers.

\subsection{Religious classes in Mosques}

The class consists of one religious instructor sitting in front of his students reading traditional Islamic texts related to faith, ethics and laws. Students sit around the instructor and listening to his teachings. The teaching is in the form of halaqah. There are four categories of religious classes conducted by different group of instructors' namely weekly Aqidah classes, Fardhu Ain classes, Fardhu Kifayah, and other religious programs (Abdullah, 2011). Based on the unstructured interviews, it was found that Aqidah classes received great number of students compared to other religious programs. Majority of the students are the elderly aged varies between 30 to 60 years old. Factor contributed to this positive response was that the classes are organized according to the students' needs and the instructors' teaching ability in attracting students' attendence to the mosques. This include his ability to customize his talk with students of all levels and their ability to make student felt unbored and laugh while listening to examples given related to the teaching.

An in-depth interviews with some of the respondents showed that their attendance to religious classes are due to their own willing to deepen religious knowledge as a preparation for life in the hereafter. Religious instructors appointed by the government and most of them are religious teachers in schools and pondok. Classical text books used normally based on instructors' preference and mastery such as Sairus Salikin, Faridah, Munyatul Musolli and some others. Most of the instructors are capable in understanding Jawi (Malay inscription) writings or Arabic language or both. The use of traditional Arabic text book as teaching materials seems to be not of interest to some students even though they are reluctant or less agrees to listen to religious teaching without text books. Looking to the demographic profile, it was clearly stated that many of the respondents coming from those with low incomes and academic qualification. They work as farmers and fishermen and thus, did not have Arabic mastery and did not even understand Arabic texts. The overall findings however revealed that majority of respondents are happy with their instructors and the latters' method of teaching since the instructor successfully manage to elaborate the Arabic text clearly and suit with the real scenario of their daily life.

In general, teaching environment in the mosque is in the form of non-formal style whereas student can come and go whilst listening to the teaching session. There are question and answer sessions which related to the daily life of the students. In this regard, the mosque management committee needs to play an important role to create a more conducive environment so that the learning session will be more attractive with modern teaching aids such as PA system and airconditioning halls. This as one respondent notes 'feel comfortable and ready to be in the hall till the morning...'.(Azhar, 2013)

\subsection{Religious Classes in Pondok Schools}

Religious class in pondok schools in this article refers to two pondok schools namely Pondok Dar al-Salam and Pondok Moden (INSPI, Pondok Darul Iman). Pondok Moden is fully sponsored by Islamic Foundation Terengganu (YIT) and MAIDAM, while the other private pondok schools only receive financial supports from MAIDAM. There are more than 30 registered pondok in Terengganu. In regard to the teaching methods of these pondok, most of the schools apply similar methods where study circle (halaqah) become popular methods. At Pondok Dar Salam, the class schedule is depicted in Table 1.

Table 1: Class Schedule in Pondok School

\begin{tabular}{|c|l|c|}
\hline Time & Lesson & Venue \\
\hline After Fajr Prayer 6.00-7.15am & Reading Classical Text (Aqidah/Fiqh/Sirah/Akhlaq & Mosque \\
\hline $8.00-12.30 \mathrm{pm}$ & Formal religious classes & Classroom \\
\hline After Zuhr Prayer 1.30-2.30pm & Reading Classical Text (Aqidah/Fiqh/Sirah/Akhlaq & Mosque \\
\hline After Asar Prayer 4.30-5.30 & Reading Classical Text (Aqidah/Fiqh/Sirah/Akhlaq & Mosque \\
\hline After Maghrib Prayer & Reading Classical Text (Aqidah/Fiqh/Sirah/Akhlaq & Mosque \\
\hline
\end{tabular}

From the schedule, it clearly states that classical texts become the most popular source for teachings. Those instructors 
should be someone capable and mastery of reading and understanding Jawi writings and Arabic writing and syntax. Normally pondok instructors are appointed from former student of the same institutions or those graduating from Middle East universities such as al-Azhar University in Cairo and Medinah Islamic University in Saudi Arabia. Amongst well known classical books used are Jawharat al-Tawhid, Sirah Nurul Yakin, Hisyiyah Bajuri, Sairus Salikin, Tafsir Jalalain, Bulugh al Maram, Syarah Ibn Aqil, Kawakib ad-Duriyyah, Matan Arbain An-Nawawi, Hashiyah Dusuki Ala- Ummil Barahin and several others.

Teaching classical text session usually conducted through one way method from the instructor, who will read the text, explain its meaning and content together with examples, whilst students listen and make notes. This method is also known as content centered activity. The session is so important because it touches on important Islamic teachings related to divinely attributes, permissible (halal) and forbidden (haram) actions in Islamic teachings, something related to ghaibiyyat and samilyyat (unseen world) and thus necessitates students to fully concentrate on the lessons. In this regard, utilizing human sense such as hearing sense and observing are so important throughout the session. Those brilliant students are appointed as Ketua Mutala'ah (assistant instructor) who will be available to explain any possible questions arise after the class.

Personal visits to a number of pondok schools in Terengganu reveal that most of the schools provide opportunity for students to get involved with community services such as cleaning the Muslim cemetery, mosques and performing jenazah prayer (prayer performed upon the body of the deceased). They join together with surrounding community in Islamic festival such as celebrating the Prophet Muhammad's Birth and other religious programs. The local community is also invited to join religious classes at the pondok. This approach is good for the local Malay community to get exposure and knowledge from the classes, but to some other extents, it brings about some problems for instructor since the instructor has to ensure that his teaching and explanation are understood by all students with different background and ages. Pondok students are normally age between 13-20 years old, whilst the local community are adults whose age ranging between 30-70 years old. At the end of the study, students will be conferred a pondok certificate to conform his completion of the study.

Educational system at Pondok Moden (Inspi and Pondok Darul Iman) is different from the private pondok. There are two class sessions which is after Maghrib prayer from 7.30 till Isya prayer. The formal class begin at 8.00am till 1.00 pm. Religious class after Maghrib prayer focus on modern books such as Aqidah ahlu Sunnah wal Jamaah and the instructor read and explain the text. It is during the formal class $(8.00 \mathrm{am}-1,00 \mathrm{pm})$ that classical texts like Iqna', Sabilal Muhtadin and Kifayatul Ahyar are taught to students. This mean that religious class at Pondok Moden differ from the private pondok in that the latter focus on classical texts after five daily prayers. Another different aspect is that Pondok Moden offer formal certificate for students namely certificate for Itmamum Dirasah, STAM and Diploma of Tahfiz alQuran. With this certificate, students are able to further their study up to the university level. Most of the certificates are recognized by the government and JAKIM in particular. It seems at this point that religious education at Pondok Moden are more towards exam oriented whereas religious education at private pondok is more towards preparing students with skills as a Muslim preacher in the societal life.

\subsection{Role of Religious Education to the Malay Community}

As noted earlier, religious educations in the mosques and pondoks have successfully received good response from the Malay community and thus showing its relevant to the current needs of Muslims. Eventhough religious classes in the mosques are less strict as compared to the pondok system, both classes offer opportunity for the sorrounding community to study and to deepen their Islamic knowledge. The running of religious classes in the mosques for instance, enable Muslims to strengthen their brotherhood and relationship amongst them regardless of their economic status, educational background and social status as a whole. After the class session, food and beverage are served and sponsored by the mosques or inviduals for all attendees. This practice successfully attract other fellow Muslims to attend Mosques' activities. Majority of the respondents acknowledge after attending religious classes, their knowledge about Islam enhance and they have a fear feelings to commit sins. The appointment of good religious instructors understanding the spiritual needs of their students will also enhance the smooth of the classes as the students feel that their teacher knows how to solve their daily spiritual problems.

The objective of pondok system of education is more towards producing students with skills as a Muslim preacher to suit with the community spiritual needs. However, with the establishment of Pondok Moden where students may receive certificate of completion throughout their study, it open the new era for the pondok educational system. More importantly, both pondok schools has provided students with strong basic knowledge and skills as well as Islamic worldview as a vanguard for them in facing current social problems such as drug addiction, free sex and other hedonistic 
life.

\section{Conclusion}

From the above discussion, it is clear that the government's supports for religious education in mosques and pondok are immense. Through Directorate of Islamic progress in Malaysia (JAKIM), State Islamic Religious Departments, and Counsel for Islamic and Malay Cultural Affairs (Maidam), various educational programs under the names of Takmir, KAFA, Muallaim and Da'i were introduced. Most of the financial supports came from the zakat collections of individual Muslims and Islamic organizations. In Terengganu, Counsel for Islamic and Malay Cultural Affairs (MAIDAM) is responsible for collecting zakat from those eligible Muslims and later distributed the money to the religious activities in mosques and pondok. These institutions are then responsible in preparing students with basic Islamic teachings in regards to life, divinely attributes, permissible and forbidden action and human interactions one another through non formal educations discussed earlier. Thus, proper management of the appropriate religious education and class in both mosques and pondok schools is vital, coupled with continuous supports from the exiting authorities so that it would not only bring spiritual benefits for the Muslims but make these form of non-formal educations in line with the current needs of Muslims. In additions, selection of good religious instructors with vase knowledge and experience will attract surrounding Muslim community to attend to their classes. With the advancement of technology, there is a need for some modifications in conducting religious classes in terms of teaching methods and the use of modern teaching facilities such as slide show and power point so that there will be interactive learning environment between students and their instructor. This is important because teaching is not a linear, one-way delivery of knowledge, but an interactive process which requires adapting to shifting contexts, demands of content, and student input.

\section{References}

Abdullah Mohamed. 2011. Kajian penilaian program pemantapan aqidah di masjid negeri Terengganu'. PhD Thesis. Kuala Terengganu: Universiti Malaysia Terengganu.

Abdul Rahman Embong \& Tham Siew Yean. 2011. Malaysia at a crossroads: can we make the transition?.Bangi: UKM Publication.

Ahmad Shalabi. 1973. Tarikh al-tarbiyyah al-Islamiyyah. Cairo: Dar al-Ittihad al-Arabi lil Tiba'ah.

Awang Koding. 2003. Heritage of Terengganu. Kuala Terengganu: KUSTEM.

Azhar Idrus. 2013. Personal interview. 28 September.

Azmi Tengah. 2014. Personal interview, 20 Mac.

Al-Būtiy. 1999. Fiqh al-sīrah al-nabawīyyah. Beirut: Dār al-Fikr al-Muāsīr.

Chelliah, M. 1947. A short history of the education policy of straits settlement. Kuala Lumpur: Government Press.

Firdaus Khairi. 2014. Personal interview, 10 Mac.

Khalid Abd Rahman.2014. Personal interview. 18 April.

Harun Din \& Sobri Salamun. 1980. Masalah pendidikan Islam di Malaysia. Kajang: Sincere Press Ltd.

Muhammad Uthman al Muhammady. 2006. Institusi masjid yang bersifat futuristik. Paper presented at Konvensyen ke Arah Pemantapan Institusi Masjid 30 Januari 1997 di Pan Pacific Kuala lumpur.

Wan Husein Azmi. 1980. Islam di Malaysia: Kedatangan dan perkembangan (Abd 7-20M). in Khoo Kay Kim. Melaka dan sejarahnya. Kuala Lumpur: Persatuan Sejarah Malaysia.

Muhammad Abu Bakar. 1991. Tok Syeikh Duyong, in Muhammad Abu Bakar (ed.). Ulama Terengganu: Suatu sorotan. Kuala Lumpur: Utusan Publication \& Distributors.

Newman, W. L. 2006. Social research method: Qualitative and quantitative approach. Boston: Pearson

Ololube and Egbezor, 2012. A critical assessment to the role/importance of non-formal education to human and national development in Nigeria: Future Trends. International Journal of Scientific Research in Education, 5 (2): 71 - 93.

Shafie Abu Bakar.1985. Institusi pondok dan kesan pendidikan di zaman silam. Islamika. V.3. 198.

SM Naquib al-Attas. 1970. The correct date of Terengganu inscription. Kuala Lumpur: Muzium Negara.

Winstedt, R.O. 1961. The Malays, a cultural history. London: Routledge and Kegan Paul Ltd.

Yegidis, B. L. \& Weinbach, R. W. 2002. Research method for social workers. Boston: Allyn and Bacon. 